\title{
The Impact of Democracy on Poverty Levels
}

\author{
Kristobal Miguel Meléndez Aguilar \\ Public Policy PhD Candidate at ITESM (Mexico City) \\ Researcher of the Center of Economic and Budgetary Research (CIEP) \\ Email:kmelendeza@hotmail.com
}

\section{Doi:10.5901/ajis.2016.v5n3s1p491}

\begin{abstract}
Robert Dahl argued that individuals living in a democracy can find better alternatives to meet basic needs such as food, health, education and housing. However, there are two assumptions that cast doubt on this hypothesis. First, democracies are usually developed in more unequal contexts. Second, on democracy, inequality can generate higher levels of poverty. By applying multiple linear regressions and instrumental-variables regressions, it was found that, in a democracy, both the context and citizens could influence on decreasing poverty levels. Procedural elements are essential to generate better contexts and citizens, through different types of participation, can influence the government to offer better public policies, especially those related to poverty levels. Higher citizen participation levels and with better procedural elements, individuals could perceive that their democracy is of higher quality and they would support more this type of regime. In the analysis also it was found that per capita income level is an important indicator of efficiency of citizen participation because political action is only efficient in rich democracies.
\end{abstract}

Keywords: Democracy, Poverty, Non democratic regimes, Citizen participation, Inequality

\section{Introduction}

Economic, political and social performance depend on a variety of factors. Type of regime and per capita income are two variables that influence on the levels of performance. Compared to other types of regime, democracies, on average, have better levels of wealth, industrialization, education and urbanization ${ }^{1}$. In addition, individuals under this type of regimen could find better alternatives to meet basic needs such as food, health, education and housing ${ }^{2}$. However, the averages do not consider the dispersion of the distribution of resources. For Ansell and Samuels ${ }^{3}$, democracies often arise in more unequal environments. For this reason, whenever analyzing economic, political and social performance, it is essential to analyze the distribution of this among society.

A democratic regime that is representative must see for the interests of the whole society. In low per capita income countries, poverty levels could be one of the main interests of society. In developing countries, citizens associate democracy as the best way to achieve higher standards of living 4 . Democracies have better political and social results than other types of regime. However, the public policies of poor democracies do not differ much from those of poor non democratic countries ${ }^{5}$. Democracies are failing to offer public policies that benefit the poorest, even though they allocate more resources to provide better services to society than non democratic countries. The middle class and the richest are those who benefit most from this type of regime ${ }^{6}$.

The poorest have the hope that their economic and social situation improves with the time. They expect that a democratic regime give them sufficient conditions to improve. In a democracy, individuals have freedoms that allow them to express opinions or influence governments to obtain more and better public policies. The poorest have the possibility of demanding programs that reduce poverty levels.

1 Seymour Lipset. (1959). "Some Social Requisites of Democracy: Economic Development and Political Legitimacy". In The AmericanPolitical Science Review. 53. 1. p. 76.

2 Robert Dahl. (1998). La democracia: una guía para los ciudadanos. Mexico. Taurus. p. 73.

3 Ben Ansell and David Samuels. (2014). Inequality and Democratization: An Elite-Competition Approach. Cambridge University Press. p.6. 4 Marc Saxer. (2009). Performance Matters - Challenges for the Democratic Model and Democracy Promotion. Friedrich Ebert Stiftung Briefing Paper 6. April. p. 3.

5 Philip Keefer. (2007). "The poor performance of poor democracies". In Carles Boix and Susan Stokes. The Oxford Handbooks of Policial Science. Oxford University Press. p.888.

6 Michael Ross. (2006). Is Democracy Good for the Poor? In American Journal of Political Science. 50. 4. p. 860. 
Poverty levels could be determined through minimum levels of consumption? ${ }^{7}$. However, it is not easy to determine what these are. The most indispensable for a decent life could be food, health, education and housing. In this way, poverty could be measured in a multidimensional way. However, each need has other dimensions that make measuring poverty more complex. Although poverty could be measured with elements that go beyond biological ones, food is one of the most important aspects of poverty ${ }^{8}$. Food poverty lines could be questioned because of their lack of precision. However, food poverty could be the best approach to poverty levels.

So, what role could democracy play in reducing poverty levels? Individuals could make use of their civil liberties, such as freedom of expression, individual rights, freedom of belief and rule of law ${ }^{9}$. In addition, they could make use of peaceful political action as marches, referendums, petitions, among others. Citizen participation influences governments to develop better public policies that reduce poverty levels. However, participation in cultural groups has no effect on poverty levels. This type of participation does not necessarily come from the poorest ${ }^{10}$.

\section{Methodology}

To identify the role of democracy in reducing poverty levels, four groups of analysis were made: poor democracies, rich democracies, poor non democratic countries, and rich non democratic countries. In this way, indirectly, it could be measured the relationship between regime and per capita income through some indicators used in this research.

Descriptive statistics, simple linear regressions, multiple linear regressions and regressions with instrumental variables were applied to these groups. The unit of analysis are the countries. A country with a per capita income above 15,000 dollars is considered as a rich country. Based on the Polity IV methodology, a country is democratic or not.

The selection and combination of variables had a comprehensive review of democratic theory with the aim of validating or rejecting the arguments of important theorists on the subject. Reliable sources were used with the largest number of countries and with all regions of the world. The sources that were used are: World Bank, Freedom House, CIA World Factbook, Global Gender Gap Report, Polity IV, United Nations Development Program, Transparency International and World Values Survey.

The indicators that were used in the descriptive statistics are: per capita energy consumption, percentage of urban population, persons per vehicle, doctors per thousand inhabitants, economic growth rate, unemployment rate in persons aged 15 to 24 years, unemployment rate in persons aged over 15 years, food price volatility, life expectancy, schooling of persons over 25 years, public policy performance, anti-corruption, political stability, human development, gender equity, poverty, confidence in government, satisfied with their life, satisfied with their standard of living, satisfied with the quality of education, satisfied with the quality of health, satisfied with the treatment of the poor, Gini, palm ratio and quintile ratio.

In simple linear regressions, multiple linear regressions and regressions with instrumental variables, the independent variables that were used are: inequality, civil liberties, political action and procedural elements. The dependent variables that were used are: poverty, public policy performance, importance of democracy and perception of the quality of democracy.

\section{Democracies vs. No Democracies, Who Have More Performance?}

As shown in Chart 1, among democracies there are different levels of performance. All those democracies with a per capita income below 15,000 dollars have less performance than rich democracies. So, it is not enough to be democratic to enjoy high levels of performance. Rich democracies have higher levels of energy consumption, urbanization and schooling. They have more doctors per thousand inhabitants and more life expectancy. The number of people per vehicle, unemployment rates and food price volatility are lower. However, economic growth rates are quite lower than those of poor democracies.

Although individuals of poor democracies trust more on government, as shown in Chart 2, in these countries the levels of public policy performance, gender equity, political stability and human development are lower than those levels

7 Amartya Sen. (1992). "Sobre conceptos y medidas de pobreza". In Comercio Exterior. 42. 4. p. 2.

8 Ibid. p. 3.

9 Freedom House. (2016). Methodology. [Online] Available: https://freedomhouse.org/reportffreedom-world-2012/methodology\#. VQpJHSSFAdU (November 2, 2016).

10 Amartya Sen. Op. Cit. p. 2. 
of rich democracies. Also perceptions of levels of health, education or treatment of the poor are lower. It seems illogical that citizens trust in their government when they face high levels of corruption and their levels of poverty are much higher.

As shown in Charts 1, 2, 3 and 4, economic, political and social performance varies more by per capita income than by type of regime. On average, independenly of their regime, rich countries have higher energy consumption, percentage of urban population, doctors per thousand inhabitants, life expectancy, schooling of persons over 25 years, public policy performance, anti-corruption programs, political stability, human development and gender equity. In rich countries, citizens are more satisfied with their lives, with their quality of education, with their quality of health and with the treatment of the poor. On average, independenly of their regime, rich countries have lower number of people per vehicle, unemployment rates, food price volatility and poverty levels. However, on average, independenly of their regime, rich countries have lower economic growth rates.

Chart 1: Comparison of performance of democratic countries by per capita income in 2013

Per capita energy consumption
Percentage of urban population
Persons per vehicle
Doctors per thousand inhabitants
Economic growth rate
Unemployment rate (over 15 years)
Unemployment rate (15-24 years)
Food price volatility
Life expectancy
Schooling of persons over 25 years

Above 15,000 dollars
$6740.63 \mathrm{Kwh}$
$73.41 \%$
2.71 persons
3.01 doctors
$1.30 \%$
$8.94 \%$
$20.93 \%$
$26.67 \%$
78.6 years
10.97 years
Below 15,000 dollars $1524.09 \mathrm{Kwh}$ $48.26 \%$ 30.09 persons 0.82 doctors $5.08 \%$ $11.07 \%$
$21.70 \%$ $39.57 \%$ 66.61 years 6.51 years

Source: Compiled by author based on Polity IV, World Bank and PNUD

Chart 2: Performance of government of democratic countries by per capita income in 2013

Public policy performance
Anti-corruption
Political stability
Human Development
Gender equity
Poverty
Confidence in government
Satisfied with their life
Satisfied with their standard of living
Satisfied with the quality of education
Satisfied with the quality of health
Satisfied with the treatment of the poor

Above $\mathbf{1 5 , 0 0 0}$ dollars
7.35
6.09
7.71
8.87
6.79
$15.41 \%$
$39.87 \%$
6.34
$68.33 \%$
$64.49 \%$
$67.56 \%$
$35.48 \%$

Below 15,000 dollars
4.12
2.48
6.1
4.78
5.97
$40.33 \%$
$46.08 \%$
5.08
$49.46 \%$
$63.09 \%$
$47.73 \%$
$30.55 \%$

Source: Compiled by author based on Polity IV, World Bank, UNDP. World Economic Forum, Transparency International and $\mathrm{CIA}$

Chart 3: Comparison of performance of non democratic countries by per capita income in 2013

Per capita energy consumption
Percentage of urban population
Persons per vehicle
Doctors per thousand inhabitants
Economic growth rate
Unemployment rate (over 15 years)
Unemployment rate (15-24 years)
Food price volatility
Life expectancy
Schooling of persons over 25 years

Above 15,000 dollars
$6329.34 \mathrm{Kwh}$
$74.94 \%$
4.26 persons
2.73 doctors
$2.36 \%$
$5.10 \%$
$10.82 \%$
$34.95 \%$
71.48 years
9.03 years

Below 15,000 dollars
$977.71 \mathrm{Kwh}$
$40.78 \%$
65.21 persons
0.79 doctors
$3.91 \%$
$9.82 \%$
$20.71 \%$
$46.05 \%$
64.44 years
5.61 years

Source: Compiled by author based on Polity IV, World Bank y UNDP 
As shown in Charts 2 and 4, on average, in non democratic countries, confidence in government is higher in rich countries. However, in democratic countries, confidence in government is higher in poor countries. On average, poor democratic countries have high poverty levels and inequality. The people of this type of regime trust that the government could solve these problems. Then, as research hypothesis, in poor democracies, despite developing in high economic inequality environments, there are conditions that help to reduce poverty levels.

\section{Inequality Levels}

As shown in Chart 5, democracies are more unequal than other types of regimes. The Gini is similar in those countries with a per capita income above 15,000 dollars. In poor countries, democracies have a higher gini. Independenly of the income level, palm ratio and quintile ratio are substantially higher in democratic countries. Chart 5 shows that poor countries are more unequal than rich countries. Therefore, poor democracies, on average, are the most unequal countries in the world.

Chart 4: Performance of government of non democratic countries by per capita income in 2013

$\begin{array}{lcc} & \text { Above } \mathbf{1 5 , 0 0 0} \text { dollars } & \text { Below } \mathbf{1 5 , 0 0 0} \text { dollars } \\ \text { Public policy performance } & 4.41 & 3.38 \\ \text { Anti-corruption } & 3.35 & 1.75 \\ \text { Political stability } & 6.7 & 4.96 \\ \text { Human Development } & 7.5 & 3.92 \\ \text { Gender equity } & 5.18 & 4.89 \\ \text { Poverty } & 20.77 \% & 37.61 \% \\ \text { Confidence in government } & 63.75 \% & 53.80 \% \\ \text { Satisfied with their life } & 5.99 & 4.56 \\ \text { Satisfied with their standard of living } & 66.14 \% & 48.72 \% \\ \text { Satisfied with the quality of education } & 61.46 \% & 58.50 \% \\ \text { Satisfied with the quality of health } & 57.29 \% & 46.44 \% \\ \text { Satisfied with the treatment of the poor } & 54.00 \% & 37.04 \%\end{array}$

Source: Compiled by author based on Polity IV, World Bank, UNDP, World Economic Forum, Transparency International and $\mathrm{CIA}$

Chart 5: Inequality levels by type of regime and by income level 2010

$\begin{array}{lcccc}\text { Above 15,000 dollars } & \text { Democracies } & \text { N } & \text { Non democracies } & \text { N } \\ \text { Gini } & 35.35 & 33 & 36.67 & 7 \\ \text { Palma ratio } & 1.93 & 15 & 1.62 & 6 \\ \text { Quintile ratio } & 7.68 & 19 & 7.60 & 7 \\ \text { Below 15,000 dollars } & & & & \\ \text { Gini } & 44.42 & 39 & 39.71 & 50 \\ \text { Palma ratio } & 2.64 & 34 & 1.93 & 47 \\ \text { Quintile ratio } & 12.06 & 37 & 7.58 & 48\end{array}$

Source: Compiled by author based on Polity IV and World Bank

Chart 6 shows that inequality has an impact on poverty levels. This effect depends on per capita income and type of regime. Inequality has a greater impact on democracies than on any other type of regime. However, in rich countries, the effect of inequality is more perceived.

Chart 6: Impact of inequality on poverty levels

$\begin{array}{lccccc} & \mathbf{n} & \text { Coefficient } & \mathbf{P}>|\mathbf{t}| & \text { R-squared } & \text { Prob }>\text { F } \\ \text { Democratic countries } & 67 & 1.036448 & 0,000 & 0.9090 & 0.0000 \\ \text { Above 15,000 dollars } & 31 & 1.089422 & 0,000 & 0.9453 & 0.0000 \\ \text { Below 15,000 dollars } & 36 & .9576558 & 0,000 & 0.8555 & 0.0000 \\ \text { Non democratic countries } & 45 & .9317474 & 0,000 & 0.8900 & 0.0000 \\ \text { Above 15,000 dollars } & 5 & 1.001414 & 0,000 & 0.9649 & 0.0005 \\ \text { Below 15,000 dollars } & 40 & .9199682 & 0,000 & 0.8774 & 0.0000\end{array}$

Source: Compiled by author based on Polity IV and CIA 
If democracies tend to develop in more unequal contexts and if inequality could lead to higher levels of poverty in democratic settings, then it is interesting to analyze whether or not the assumption that individuals living in a democracy could find better alternatives to satisfy basic needs such as food, health, education and housing ${ }^{11}$.

The effect that democracy could have on poverty levels could be analyzed from two perspectives: from the actions of citizens and from the democratic context. Taking into account the first perspective, compared to political action, as shown in Chart 7, civil liberties have a greater impact on poverty levels. Civil liberties have a greater impact on levels of poverty in democratic countries than any other type of regime. Political action is only effective in rich countries. Then, poor democracies with high levels of inequality could substantially improve their poverty levels if they strengthen their civil liberties.

As shown in Charts 7 and 8, civil liberties and political action have a lower impact on public policy performance than on reducing poverty levels. Political action is only significant in rich democracies.

Chart 7: Impact of civil liberties and political action on poverty levels

\begin{tabular}{|c|c|c|c|c|c|}
\hline Democratic countries & n & Coefficient & $P>|t|$ & $\begin{array}{c}\text { R-squared } \\
0.8733\end{array}$ & $\begin{array}{c}\text { Prob }>F \\
0.0000\end{array}$ \\
\hline Civil liberties & & 1.710759 & 0.000 & & \\
\hline Political action & & 1.085623 & 0.000 & & \\
\hline Above 15,000 dollars & 16 & & & 0.9132 & 0.0000 \\
\hline Civil liberties & & 1.938276 & 0.000 & & \\
\hline Political action & & 1.159732 & 0.000 & & \\
\hline Below 15,000 dollars & 5 & & & 0.9455 & 0.0127 \\
\hline Civil liberties & & 2.779450 & 0.018 & & \\
\hline Political action & & -0.781939 & 0.259 & & \\
\hline Non democratic countries & 19 & & & 0.9003 & 0.0000 \\
\hline Civil liberties & & 1.505558 & 0.000 & & \\
\hline Political action & & -.3344512 & 0.227 & & \\
\hline Above 15,000 dollars & 4 & & & 0.9934 & 0.0066 \\
\hline Civil liberties & & 1.628131 & 0.008 & & \\
\hline Political action & & -0.393978 & 0.353 & & \\
\hline Below 15,000 dollars & 15 & & & 0.8654 & 0.0000 \\
\hline Civil liberties & & 1.453587 & 0.000 & & \\
\hline Political action & & -0.302377 & 0.362 & & \\
\hline
\end{tabular}

Source: Compiled by author based on Polity IV, CIA, Freedom House and World Values Survey

Taking into account the second perspective, as shown in Chart 9, procedural elements have a greater impact on poverty levels in non democratic countries. However, these elements also contribute to lower poverty levels in democracies. This impact is greater in poor democracies.

As shown in Chart 10, political action is less effective in reducing poverty levels when inequality levels decline. In these circumstances, political action only reduces poverty levels in rich democracies. Conversely, civil liberties take a greater force to reduce poverty levels when inequality levels decline.

Chart 8: Impact of civil liberties and political action on public policy performance

\begin{tabular}{|c|c|c|c|c|c|}
\hline Democratic countries & $\begin{array}{c}n \\
26\end{array}$ & Coefficient & $P>|t|$ & $\begin{array}{c}\text { R-squared } \\
0.8918\end{array}$ & $\begin{array}{c}\text { Prob }>F \\
0.0000\end{array}$ \\
\hline Civil liberties & & 1.247889 & 0.000 & & \\
\hline Political action & & 1.02038 & 0.000 & & \\
\hline Above 15,000 dollars & 21 & & & 0.9050 & 0.0000 \\
\hline $\begin{array}{l}\text { Civil liberties } \\
\text { Political action }\end{array}$ & & $\begin{array}{l}1.444165 \\
1.024800\end{array}$ & $\begin{array}{l}0.000 \\
0.000\end{array}$ & & \\
\hline Below 15,000 dollars & 5 & & & 0.9632 & 0.0070 \\
\hline Civil liberties & & 1.849044 & 0.018 & & \\
\hline Political action & & -.1376561 & 0.738 & & \\
\hline
\end{tabular}




$\begin{array}{cccccc}\begin{array}{c}\text { Non democratic countries } \\ \text { Civil liberties }\end{array} & 19 & & & 0.8610 & 0.0000 \\ \quad \text { Political action } & & .8708386 & 0.000 & & \\ \text { Above } 15,000 \text { dollars } & 4 & -.2609612 & 0.165 & & \\ \quad \text { Civil liberties } & & .9289487 & 0.033 & & 0.9575 \\ \quad \begin{array}{l}\text { Political action } \\ \text { Below 15,000 dollars }\end{array} & 15 & -.7506114 & 0.198 & & \\ \quad \text { Civil liberties } & & .8954156 & 0.000 & 0.8540 & 0.0000 \\ \quad \text { Political action } & & -.2285645 & 0.279 & & \end{array}$

Source: Compiled by author based on Polity IV, CIA, Freedom House and World Values Survey

Chart 9: Impact of procedural elements on poverty levels

$\begin{array}{cccccc} & \mathbf{n} & \text { Coefficient } & \mathbf{P}>|\mathbf{t}| & \text { R-squared } & \text { Prob > F } \\ \text { Democratic countries } & 71 & 1.181338 & 0,000 & 0.9310 & 0.0000 \\ \text { Above 15,000 dollars } & 32 & 1.141667 & 0,000 & 0.9553 & 0.0000 \\ \text { Below 15,000 dollars } & 39 & 1.272372 & 0,000 & 0.8955 & 0.0000 \\ \text { Non democratic countries } & 58 & 1.888005 & 0,000 & 0.8392 & 0.0000 \\ \text { Above 15,000 dollars } & 7 & 2.253752 & 0,000 & 0.8653 & 0.0008 \\ \text { Below 15,000 dollars } & 51 & 1.832332 & 0,000 & 0.8393 & 0.0000\end{array}$

Source: Compiled by author based on Polity IV, CIA, World Bank and Transparency International

When poverty levels and inequality decrease, as shown in Charts 11 and 12, civil liberties have a very significant indirect effect on citizens' perception of whether or not democracy is important and whether or not this type of regime is of quality. This effect is greater in democratic countries. However, there is also an important effect in non democratic countries. Political action only has significance in the perceptions of the citizens of rich democracies so that they think that democracy is important or that this type of regime is of quality.

As shown in Charts 8 and 13, when poverty levels and inequality decline, civil liberties and political action are more effective to promote better public policies. Political action only has a major impact on promoting better public policies in rich democracies.

Chart 10: Impact of civil liberties and political action on poverty levels with the indirect effect of inequality

\begin{tabular}{|c|c|c|c|}
\hline & $\mathrm{n}$ & Coefficient & $P>|t|$ \\
\hline Democratic countries & 19 & & \\
\hline Civil liberties & & 3.551066 & 0.000 \\
\hline Political action & & .4804886 & 0.204 \\
\hline Above 15,000 dollars & 14 & & \\
\hline Civil liberties & & 3.578117 & 0.000 \\
\hline Political action & & .7923726 & 0.003 \\
\hline Below 15,000 dollars & 5 & & \\
\hline Civil liberties & & 3.450519 & 0.000 \\
\hline Political action & & -1.337274 & 0.030 \\
\hline Non democratic countries & 17 & & \\
\hline Civil liberties & & 1.683615 & 0.000 \\
\hline Political action & & -.5216019 & 0.067 \\
\hline Above 15,000 dollars & 3 & & \\
\hline Civil liberties & & 1.543398 & 0.000 \\
\hline Political action & & .4249544 & 0.194 \\
\hline Below 15,000 dollars & 14 & & \\
\hline Civil liberties & & 1.697732 & 0.000 \\
\hline Political action & & -.5466747 & 0.104 \\
\hline
\end{tabular}

Source: Compiled by author based on Polity IV, CIA, Freedom House and World Values Survey 
Chart 11: Impact of civil liberties and political action on importance of democracy with the indirect effect of inequality and poverty levels

$\begin{array}{cccc} & \mathrm{n} & \text { Coefficient } & \mathrm{P}>|\mathbf{t}| \\ \begin{array}{c}\text { Democratic countries } \\ \text { Civil liberties }\end{array} & 19 & 3.175634 & 0.000 \\ \quad \begin{array}{c}\text { Political action } \\ \text { Above 15,000 dollars }\end{array} & & .8096089 & 0.000 \\ \quad \text { Civil liberties } & 14 & & \\ \quad \begin{array}{l}\text { Political action } \\ \text { Below 15,000 dollars }\end{array} & & 2.847841 & 0.000 \\ \quad \text { Civil liberties } & 5 & 1.067931 & 0.000 \\ \quad \begin{array}{l}\text { Political action } \\ \text { Non democratic countries }\end{array} & & 3.507659 & 0.000 \\ \quad \text { Civil liberties } & 17 & -.473336 & 0.328 \\ \quad \text { Political action } & & 1.753333 & 0.000 \\ \text { Above 15,000 dollars } & & .017785 & 0.910 \\ \quad \text { Civil liberties } & 3 & 1.688642 & 0.000 \\ \quad \text { Political action } & & -.4920003 & 0.107 \\ \text { Below 15,000 dollars } & & & \\ \quad \text { Civil liberties } & 14 & 1.816774 & 0.000 \\ \text { Political action } & & -.0325026 & 0.860\end{array}$

Source: Compiled by author based on Polity IV, CIA, Freedom House and World Values Survey

Chart 12: Impact of civil liberties and political action on perception of quality of democracy with the indirect effect of inequality and poverty levels

\begin{tabular}{|c|c|c|c|}
\hline & $\mathrm{n}$ & Coefficient & $P>|t|$ \\
\hline Democratic countries & 19 & & \\
\hline Civil liberties & & 3.091091 & 0.000 \\
\hline Political action & & .8159014 & 0.000 \\
\hline Above 15,000 dollars & 14 & & \\
\hline Civil liberties & & 2.720656 & 0.000 \\
\hline Political action & & 1.063342 & 0.000 \\
\hline Below 15,000 dollars & 5 & & \\
\hline Civil liberties & & 3.694329 & 0.000 \\
\hline Political action & & -.5577251 & 0.410 \\
\hline Non democratic countries & 17 & & \\
\hline Civil liberties & & 1.692364 & 0.000 \\
\hline Political action & & .1382068 & 0.451 \\
\hline Above 15,000 dollars & 3 & & \\
\hline Civil liberties & & 1.702888 & 0.000 \\
\hline Political action & & -.8819636 & 0.058 \\
\hline Below 15,000 dollars & 14 & & \\
\hline Civil liberties & & 1.750451 & 0.000 \\
\hline Political action & & .0990849 & 0.636 \\
\hline
\end{tabular}

Source: Compiled by author based on Polity IV, CIA, Freedom House and World Values Survey

Chart 13: Impact of civil liberties and political action on public policy performance with the indirect effect of inequality and poverty levels

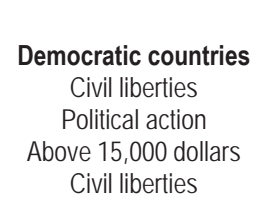

$\begin{array}{ccc}\mathbf{n} & \text { Coefficient } & \mathrm{P}>|\mathbf{t}| \\ 19 & & \\ & 2.324857 & 0.000 \\ & .7555084 & 0.002 \\ 14 & 2.16710 & 0.000\end{array}$




\begin{tabular}{|c|c|c|}
\hline \multirow{2}{*}{5} & 1.014462 & 0.000 \\
\hline & 2.020243 & 0.000 \\
\hline \multirow{3}{*}{17} & -.2793302 & 0.364 \\
\hline & 1.023071 & 0.000 \\
\hline & -.3238622 & 0.046 \\
\hline \multicolumn{3}{|c|}{. VLUOULL } \\
\hline & .8095097 & 0.000 \\
\hline \multirow{3}{*}{14} & .3509567 & 0.188 \\
\hline & & \\
\hline & $\begin{array}{c}1.084393 \\
-.3867623\end{array}$ & $\begin{array}{l}0.000 \\
0.044\end{array}$ \\
\hline
\end{tabular}

Source: Compiled by author based on Polity IV, CIA, Freedom House and World Values Survey

\section{Conclusions}

Poor democracies have an economic performance below than other democracies and other types of regime. In addition, poor democracies have a context of high levels of inequality, this increases the risk that citizens of these democracies could begin to sympathize with non democratic regimes.

Procedural elements, civil liberties and political action help rich democracies to reduce their poverty levels and inequality; They also help to improve their public policies in general. However, unlike rich democracies, in poor democracies, political action is not significant in order to reduce poverty levels and inequality or to improve public policy performance.

When poverty levels and inequality decrease, civil liberties and procedural elements help to ensure better public policies and so that citizens support more a democratic regime because they perceive that this type of regime is of higher quality and because they believe that It is important to support it. This reduces the risk that citizens of poor democracies could sympathize with other types of regime.

\section{References}

Ansell, Ben and David Samuels. (2014). Inequality and Democratization: An Elite-Competition Approach. Cambridge University Press.

CIA World Factbook. [Online] Available: https://www.cia.gov/library/publications/the-world- factbook/ (November 2, 2016).

Dahl, Robert. (1998). La democracia: una guía para los ciudadanos. Mexico. Taurus.

Freedom House. (2016). Methodology. [Online] Available: https://freedomhouse.org/report/freedom-world-2012/methodology\#. VQpJHSSFAdU (November 2, 2016).

Global Gender Gap Report. (2009). World Economic Forum. [Online] Available: http://www.amichediabcd.org/The\%20Globa I\%20Gender\%20Gap\%20report2009.pdf (November 2, 2016).

Keefer, Philip. (2007). "The poor performance of poor democracies". In Carles Boix and Susan Stokes. The Oxford Handbooks of Policial Science. Oxford University Press.

Lipset, Seymour. (1959). "Some Social Requisites of Democracy: Economic Development and Political Legitimacy". In The AmericanPolitical Science Review. 53. 1.

Polity IV Project. (2016). Individual Country Regime Trends, 1946-2013. [Online] Available: http://www.systemicpeace.org /polity/polity4.htm (November 2, 2016).

Ross, Michael. (2006). Is Democracy Good for the Poor? In American Journal of Political Science. 50. 4.

Saxer, Marc. (2009). Performance Matters - Challenges for the Democratic Model and Democracy Promotion. Friedrich Ebert Stiftung Briefing Paper 6. April.

Sen, Amartya. (1992). "Sobre conceptos y medidas de pobreza". In Comercio Exterior. 42. 4.

The World Bank. (2016). World DataBank. [Online] Available: http://databank.worldbank.org/data/home.aspx (November 2, 2016).

The World Bank. (2009). Worldwide Governance Indicators. [Online] Available: http://info.worldbank.org/governance/w gi/ index.asp (November 2, 2016).

Transparency International. (2010). [Online] Available:http://www.transparency.org/ (November 2, 2016).

United Nations Development Programme (UNDP). (2016). Human Development Index. Online] Available: http://www.undp.org /content/undp/en/home/ (November 2, 2016).

World Values Survey. (2016). The World's Most Comprehensive Investigation of Political and Sociocultural Change. [Online] Available: http://www.worldvaluessurvey.org. (November 2, 2016). 